\title{
Development of E-Book Teaching Materials Based on The Problem Based Instruction Course of Instruction Management Courses in Indonesian Literature Students UNIMED
}

\author{
$1^{\text {st }}$ Hera Chairunisa ${ }^{1}, 2^{\text {nd }}$ Ita Khairani ${ }^{2}, 3^{\text {rd }}$ Muharrina Harahap ${ }^{3}$ \\ \{herawenas@unimed.ac.id ${ }^{1}$, itakhairanie@ rocketmail.com² hrpmuharrina@gmail.com $\left.^{3}\right\}$ \\ Indonesian Language and Literature Study Program, Faculty of Languages and Arts, Universitas \\ Negeri Medan, Indonesia ${ }^{1,2,3}$
}

\begin{abstract}
This study aims to: (1) To develop product development of E-Book Teaching Materials Based on Problem Based Instruction Model for Performance Management Courses for Indonesian Literature Students Unimed. (2) To describe the product usage of E-Book Teaching Materials Based on Problem Based Instruction Model for Performance Management Courses for Indonesian Literature Students Unimed. (3) To test the effectiveness of the product of E-Book Teaching Materials Based on Problem Based Instruction Models for Performance Management Courses for Indonesian Literature Students Unimed. The research method uses research and development (R\&D) methods from the ADDIE R\&D model (Analysis, Design, Development, Implementation, and Evaluation). The results of research conducted in the development of E-Book Teaching Materials Product Development Based on Problem Based Instruction Models for the Performance Management Course received a percentage of feasibility/validity as many as $92 \%$ of material experts, $90.6 \%$ of media experts, and $93.3 \%$ of management learning experts show. Product Development Effectiveness of E-Book Teaching Materials Based on Problem Based Instruction Models for Performance Management Courses based on Pre-Test, Post-Test, and t-test. The results of the Pre-Test showed that 9 students or as many as $45 \%$ completed, with an average score of 63.5 . The results of the Post-Test test of student completeness increased from before, namely 17 students who got a complete score or as much as $85 \%$, with an average score of 80 . There is a significant difference between student learning outcomes before and after using E-Book Teaching Materials Based on Problem Based Instruction Models for Performance Management Courses. Thus, it can be concluded that the product of E-Book Teaching Materials Based on the Problem Based Instruction Model for the Performance Management Course is feasible, practical, and effective to be used for Unimed Indonesian Literature Students.
\end{abstract}

Keywords: Teaching Materials, E-Books, Models, Problem Based Instruction, Management, Performance.

\section{Introduction}

The Performance Management course aims to provide students with competence to have mastery of knowledge, understanding and experience which includes: Organization of the Performing Arts, basic concepts of management, the process of planning a performance, and 
organizing a performance.Learning Outcomes that are charged to the courses consist of CPL S2: Demonstrates an attitude of being responsible for work in their respective fields of expertise independently, CPL-S3: Has the ability to lead themselves and others in carrying out their responsibilities, CPL-S4: Demonstrates an attitude honest and creative in utilizing ICT in the use of learning resourcesj, CPL-S6: Having a flexible and adaptive attitude towards cultural diversity and socio-cultural values that develop in the community, CPL-S8: Cooperating and having social sensitivity and concern for society and the environment. The soft skill attributes that will be developed in students through this course are initiative, objective, analytical and logical.

The lecture method that has been running so far generally uses the lecture method, discussion, assignment of papers and practice. However, there are still many students who are passive, their involvement in discussions and analyzing problems is not monitored in performing performance management practices. This is evidenced by the results of the formative exam in the odd semester of the 2019 - 2020 academic year, the 2017 Indonesian Language and Literature Department ( $\mathrm{N}=39$ people) who got a formative score of $70 \%$ only got a fairly competent category. There are still $30 \%$ of students who are not competent. This means that students do not yet have competence in the ability to integrate the cognitive, affective, and psychomotor domains in Performance Management learning.

Connected with the spread of the corona virus pandemic or COVID-19 in Indonesia, many universities and schools have stopped the face-to-face learning process. So that researchers face a new phenomenon regarding the lecture system. Study activities at the Medan State University experienced the same impact. Referring to the results of the Circular of the Chancellor of the State University of Medan No 0809/UN.33/SE/2020, regarding the prevention and spread of Corona Virus Disease, for the 1st point in the contents of the letter, namely that the implementation of lectures and academic activities is carried out online (online). through SIPDA (http://sipda.unied.ac.id) or other applications such as edmodo, schoology, google classroom and the like.... [1]

The above problems are related to the results of face-to-face lectures for the class of 2017 who have taken the Face-to-face Performance Management course on campus, the scores obtained are $30 \%$ of students who are less competent. If the Corona Virus Pandemic continues in the odd semester of the 2020/2021 learning year for students of the 2018 class who will take the Performance Management course, it will increase the anxiety of the lecturer as a researcher regarding the competencies that will be obtained at the end of the lecture.Based on the announcement madeMinister of Education and Culture admitted that he was studying the possibility of implementing an emergency curriculum due to conditions that required studying at home during the virus pandemic corona (Covid-19). In addition, students must also be ready to adapt to changes in learning regulated by schools and universities. Remote learning can be seen as more freely and flexibly accessed from home [2].

Based on the Unimed Chancellor's circular letter and the statement from the Minister of Education and Culture as well as the issue of the Corona Virus pandemic which is uncertain when it will end, the researchers anticipate that phenomena that occur in Performance Management learning are less than optimal. By diagnosing learning outcomes, among others: (1) The difficulty of students understanding performance management, (2) The difficulty of students explaining the scope of the course, (3) being able to understand the profile of the performance organization, (4) The difficulty of students planning literary performances, and (5) It is difficult for students to organize a performance. The Performance Management learning method used previously was on line person or directly guided. 
Based on the problems above, the researcher plans the Optimization of Learning PlanningPerforming Arts courses are planned with a systemonline learning is used appropriately and clearly.So the idea of solving the issue was made, namely 'Development of E-Book Teaching Materials Based on Problem Based Instruction Model for Performance Management Courses for Indonesian Literature Students Unimed'. For this reason, researchers also took the initiative to create e-Books that are creative, interactive, interesting and informative. Thus, it is expected that the delivery of digital electronics material is more leverage, more easily understood by students, students do not feel bored in receiving lessons, and can be motivated to learn more. In addition, with e-books, it is expected that students are not only motivated during lessons but are also motivated to learn outside class hours and are able to experiment with the material presented.The title of the research title for the novice lecturer is "Development of E-Book Teaching Materials Based on Problem Based Instruction Model for Performance Management Course for Indonesian Literature Students Unimed".Through planning the development of this Digital Book, it is hoped that later it will be able to overcome existing problems such as lecture planning to be enriched and interesting for students so that it can be accessed anytime and anywhere.

\section{Method}

The researcher uses the research and development (R\&D) method from the ADDIE R\&D model (Analysis, Design, Development, Implementation, and Evaluation). According to Romiszowski ADDIE, the systematic learning design model as a procedural aspect of the systems approach has been manifested in many methodological practices for the design and development of text, materials, audiovisual and computer-based learning materials. With this research model, the product produced is in the form of a digital book with the aim of facilitating learning activities between lecturers and students who implement the achievement of educational goals. The stages of research and development include: 1. Analysis (Analysis), 2. Design (Design), 3. Development (Development), 4. Implementation (Implementation), 5. Evaluation (Evaluation) [3] The procedural chart in this study is as follows:

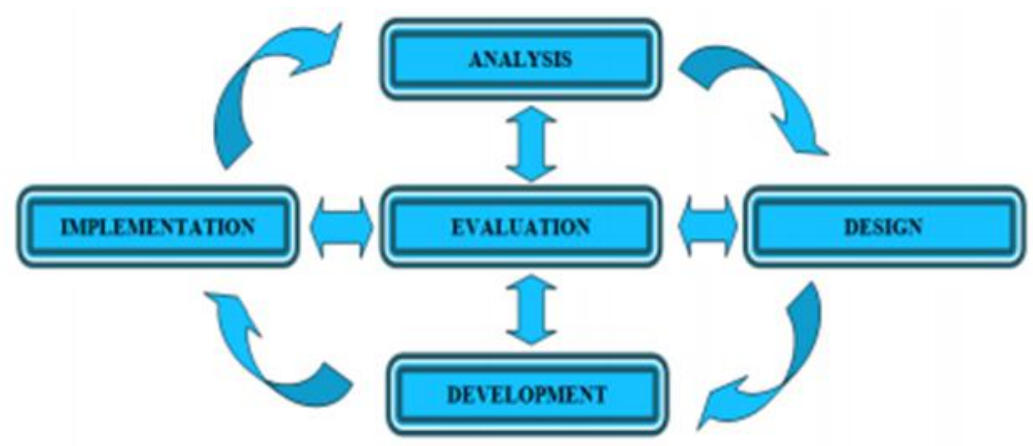

Fig. 1. Research and Development (R\&D) Method ADDIE Model [3].

This activity will be carried out at a time and place in accordance with the lectures for the Performance Management course in the Indonesian Language and Literature department. The 
population of all Indonesian Literature students in 2019 was 25 people. The research sample was the entire population of 25 Indonesian Language and Literature Study Program students in the fifth semester (V) of the 2020/2021 academic year.

\section{Results and Discussion}

The results of the study of the material expert's feasibility test were carried out twice. Based on the results of the first validation, the E-Book Teaching Materials Based on the Problem Based Instruction Model for the Performance Management Course obtained a feasibility value of $46 \%$ if adjusted to the feasibility table, so the score is included in the invalid qualification and the decision taken is a total revision. Based on the results of the validation of the two material experts on E-Book Teaching Materials Based on Problem Based Instruction Models for the Performance Management Course, the eligibility reached 92\%, adjusted for the feasibility table including the very feasible qualifications.

The media expert's assessment was obtained from a questionnaire given to the validator/media expert, the results of the media expert validation were obtained. E-Book Teaching Materials Based on Problem Based Instruction Models for Performance Management Courses with a feasibility value reaching $90.6 \%$, if adjusted to the feasibility table, the score will be included in the qualifications are very feasible and the decision taken is that there is no need for revision. Validation of Expert Practitioners is obtained. The assessment of the feasibility value reaches $93.3 \%$ if it is adjusted to the feasibility table so that the score is included in the very feasible qualification and the decision taken is that there is no need for revision. Effectiveness of E-Book Teaching Materials Based on Problem Based Instruction Models for Performance Management Courses. The achievement can be through preliminary tests and follow-up tests carried out on Semester V students of the Indonesian Language and Literature Department. Data from the Pre-Test value Used to determine the ability and level of knowledge of students before receiving treatment. In addition, students received treatment with E-Book Teaching Materials Based on the Problem Based Instruction Model that was developed, the data resulting from the treatment were obtained from the PostTest results.

The average student score obtained from 20 students is 63.5 , meaning that the learning outcomes or student learning mastery are still not good. With the number of students who completed only reached 9 people (45\%), while students who did not complete amounted to 11 people $(55 \%)$. These results are still far from the classical completeness criteria of $85 \%$. Based on the results above, the researchers carried out the learning process by providing using EBook Teaching Materials Based on Problem Based Instruction Models to determine the success rate of the learning process. Post-Test results were obtained from a total of 20 people, there were 17 students (85\%) who completed, and 3 students who did not complete (15\%). It was concluded that the percentage of students who completed was higher than students who did not complete. Thus, student learning completeness has reached classical completeness, which is $85 \%$. From the results of the Pre-Test and Post-Test scores, another analysis was carried out through a dependent t-test (Paired Sample t-test) or t-test.

This analytical technique is used to determine whether there is an effect of treatment given to research subjects through product development of E-Book Teaching Materials Based on Problem Based Instruction Models. The steps for data analysis are as follows: This analytical technique is used to determine whether there is an effect of treatment given to 
research subjects through product development of E-Book Teaching Materials Based on Problem Based Instruction Models. The steps for data analysis are as follows: This analytical technique is used to determine whether there is an effect of treatment given to research subjects through product development of E-Book Teaching Materials Based on Problem Based Instruction Models. The steps for data analysis are as follows. Based on the value obtained from the calculation of $=4.37>=2.631$ so that there is a significant average difference between student learning outcomes before and after using E-Book Teaching Materials Based on Problem Based Instruction Models, then 1 is accepted 0 is rejected. Based on the average results of the Pre-Test that $1=63.5$ and the average results of the Post-Test that $2=80$, it shows that the Post-Test results have increased by 16.5 .

The product developed in this research is the product development of E-Book Teaching Materials Based on the Problem Based Instruction Model for Performance Management Courses. The media uses the ADDIE model, namely analysis, design, development, implementation, and evaluation. The first stage is analysis, the analysis stage carried out is competency analysis, characteristic analysis, and material analysis. The second stage is design, at this stage the researcher makes a design from the things that have been analyzed based on the needs of Indonesian Language and Literature students. The steps at this stage refer to the product development of E-Book Teaching Materials Based on the Problem Based Instruction Model for the Performance Management Course and describe the interview and observation grids as an analysis of the needs of lecturers and students, planning the design of E-Book Teaching Materials Based on the Problem Based Instruction Model, as well as planning the completeness of the E-Book Teaching Materials Based on the Problem Based Instruction Model. The third stage is Development, the product begins to be developed according to the prepared design. E-Book Teaching Materials Based on the Problem Based Instruction Model starting from the collection of materials that have been made beforehand. After that, the media created will be validated by material and media experts (validators). After the media is feasible, the researchers will test the media to students. The fourth stage is Application. The implementation stage is special steps to implement the learning system, everything that is delivered is in accordance with the learning material. At this stage, the developed media will be tested. Media development is realized in the form of field tests which have a function to determine the feasibility, practicality, and effectiveness of using media in the learning process. At this stage, the researcher obtained the results of the feasibility test for the E-Book Teaching Materials Based on the Problem Based Instruction Model that was feasible and could be used as one of the teaching materials in the Performance Management Course. with the percentage of eligibility from material experts as much as $92 \%$, from media experts as much as $90.6 \%$, from learning experts as much as $93.3 \%$. At this stage, the researcher obtained the results of the feasibility test for the E-Book Teaching Materials Based on the Problem Based Instruction Model that was feasible and could be used as one of the teaching materials in the Performance Management Course. with the percentage of eligibility from material experts as much as $92 \%$, from media experts as much as $90.6 \%$, from learning experts as much as $93.3 \%$. At this stage, the researcher obtained the results of the feasibility test for the E-Book Teaching Materials Based on the Problem Based Instruction Model that was feasible and could be used as one of the teaching materials in the Performance Management Course. with the percentage of eligibility from material experts as much as $92 \%$, from media experts as much as $90.6 \%$, from learning experts as much as $93.3 \%$.

The results of the trial of the effectiveness of the use of E-Book Teaching Materials Based on the Problem Based Instruction Model improve student learning outcomes, namely the results of the pretest as many as 9 students or as many as $45 \%$ of students who completed, 
while 11 students or $55 \%$ of students did not complete, with an average score of obtained by 63.5. The results of the Post-Test mastery of students increased from the previous, namely 17 students got a complete score or as much as $85 \%$ while the other 3 students had not finished at $15 \%$, with an average score of 80 . The percentage of completeness increased from Pre-Test to Post -Test. With this it can be seen the influence of the use of E-Book Teaching Materials Based on Problem Based Instruction Models on student learning outcomes.

\section{Conclusion}

Based on the results of research and discussion, it can be concluded below. The results of the feasibility test for Product Development of E-Book Teaching Materials Based on Problem Based Instruction Models for the Performance Management Course for Indonesian Literature Students Unimed can be realized and are feasible without revision and can be used as one of the learning media with a percentage of eligibility from material experts as much as $92 \%$, from media experts as much as $90.6 \%$, from expert learning practitioners as much as $93.3 \%$. The results of the initial test (Pre-Test) obtained 9 students or as many as $45 \%$ of students who completed, while 11 students or $55 \%$ of students did not complete, with an average score of 63.5. The results of the next test (Post-Test) of student mastery increased from the previous, namely 17 students got a complete score or as much as $85 \%$ while the other 3 students had not finished at $15 \%$, with an average score of 80 . The percentage of completeness increased from Pre -Test to Post-Test. The results of the trial of the effectiveness of using E-Book Teaching Materials Based on Problem Based Instruction Models for Performance Management Courses can be seen from the use of which can improve student learning outcomes. Based on the values of the Pre-Test and Post-Test, further analysis was carried out through the t-test. Based on the value obtained from the calculation $t_{\text {hitung }}=4.37>$ ttabel $=2.631$, then $H_{1}$ accepted $H_{0}$ rejected. Based on the average Pre-Test results, it can be seen that $x_{1}=63.5$ and the average Post-Test results can be seen that $x_{2}=80$, indicating that the Post-Test results have increased by 16.5 , so there is a significant average difference between student learning outcomes before and after using E-Book Teaching Materials Based on Problem Based Instruction Models for Performance Management Courses. The product development of E-Book Teaching Materials Based on Problem Based Instruction Models for the Performance Management Course for Unimed Indonesian Literature Students is feasible, practical, and effective to use in learning.

\section{References}

[1] Gultom S. Rector's Circular. Available from: https://www.unimed.ac.id/2020/03/16/surat-edaranrector-about-action-prevention-spread-covid-19-di-unimed/ [Accessed 16 ${ }^{\text {th }}$ March 2020].

[2] Makarim N. Minister of Education and Culture Nadiem admits that he is currently reviewing the Corona Emergency Curriculum. Available from: https://www.cnnindonesia.com/nasional/20200415171950-20-493880/mendikbud-nadiem-akuitengah-kaji-kurikulum-darurat-corona [Accessed $13^{\text {th }}$ March 2021].

[3] Sugiyono. Quantitative, Qualitative and R\&D Research Methodology. Bandung: Alphabeta; 2015. 200. 